\title{
STEROID METABOLISM BY THE CHIN GLAND OF THE MALE CUIS, GALEA MUSTELOIDES
}

\author{
W. V. HOLT AND W. H. TAM* \\ Wellcome Institute of Comparative Physiology, \\ Zoological Society of London, Regent's Park, London NW1 $4 R Y$
}

(Received 25th February 1972)

\begin{abstract}
Summary. Using histochemical and in-vitro biochemical methods, the following steroid enzymes were found in the chin gland of the male cuis: $17 \beta$-hydroxysteroid dehydrogenase, 5 -ene- $3 \beta$-hydroxysteroid dehydrogenase and 4-ene- $5 \alpha$-reductase. The chin gland did not metabolize $\left[4-{ }^{14} \mathrm{C}\right]$ progesterone but it did metabolize a small quantity of $\left[7 \alpha-{ }^{3} \mathrm{H}\right]$ pregnenolone to progesterone, and readily converted $\left[4-{ }^{14} \mathrm{C}\right]-$ testosterone into androstenedione and $5 \alpha$-androstane-3,17-dione. These are catabolic products of testosterone. These findings, together with the possible rôle of the chin gland in sexual behaviour, may show that sebum has a communicative rôle in Galea musteloides and other mammals.
\end{abstract}

\section{INTRODUCTION}

The occurrence of sebaceous gland aggregates in mammals has been discussed by Montagna (1963) and Strauss \& Ebling (1970), who also reviewed the findings concerning the response of sebaceous glands to androgens. These authors showed that, in general, sebaceous glands are activated by androgens (increase in cell size and mitotic rate) and degenerate after castration. The specialized sebaceous glands have been shown to respond to androgens and to castration in a similar way. This has been shown in, amongst others, the supracaudal gland of the male guinea-pig (Martan, 1962; Martan \& Price, 1967), the side glands of shrews (Dryden \& Conaway, 1967) and the ventral gland of the gerbil (Glenn \& Gray, 1965; Mitchell, 1967; Thiessen, Friend \& Lindzey, 1968).

The chin gland of Galea musteloides appears as a convex patch of bare skin adjacent to the lower jaw and has been shown to be a complex of enlarged sebaceous glands similar to those mentioned above (Weir, 1971). A possible relationship between the chin gland and sexual behaviour in the male $G$. musteloides has been proposed by Rood \& Weir (1970) and Weir (1971), who suggested that a secretion from the chin gland of the male might be involved in the induction of oestrus in the female. Recent studies have indicated, however, that oestrus is not induced solely by the effect of this gland since males whose

* Present address: Department of Zoology, University of Western Ontario, London 72, Ontario, Canada. 
chin glands have been removed surgically are still capable of inducing oestrus when caged with a female (B. J. Weir, personal communication).

A considerable amount of research has been carried out upon the steroid metabolism of human skin but the mechanism by which the effects of androgens upon sebaceous glands are exerted is poorly understood. Wotiz, Mescon, Doppel \& Lemon (1956) demonstrated the metabolism of testosterone in vitro, and Baillie, Calman \& Milne (1965) made a thorough study of the distribution of hydroxysteroid dehydrogenases in human skin. In the present work, the distribution of steroid enzymes and the metabolism in vitro of various steroids by the chin gland of the male $G$. musteloides (a member of the family Caviidae, like the laboratory guinea-pig) were studied and an attempt is made to correlate the possible function of this gland with its steroid metabolism.

\section{MATERIALS AND METHODS}

\section{HISTOCHEMICAL TECHNIQUE}

Samples of chin gland were obtained from adult male animals of the Wellcome Institute breeding colony (Weir, 1970). Part of the tissue was quenched in isopentane at $-70^{\circ} \mathrm{C}$, and part fixed in $10 \%$ neutral buffered formalin. The frozen tissue was sectioned at $15 \mu \mathrm{m}$ in a Bright's cryostat at $-20^{\circ} \mathrm{C}$, and the fixed tissue was embedded in paraffin wax, sectioned at $5 \mu \mathrm{m}$ and stained in haematoxylin and eosin.

To demonstrate hydroxysteroid dehydrogenases, fresh frozen sections were immersed in redistilled acetone at $4^{\circ} \mathrm{C}$ for $5 \mathrm{~min}$, rinsed in distilled water and incubated for periods of up to $3 \mathrm{hr}$ at $37^{\circ} \mathrm{C}$ according to the method of Baillie, Ferguson \& Hart (1966). The substrates used were testosterone, dehydroepiandrosterone (DHEA) and pregnenolone. The reactions were controlled by incubation of adjacent sections in (1) a medium lacking the specific substrate and (2) a medium containing nitroblue tetrazolium (NBT) only. The presence of reduced nicotinamide-adenine dinucleotide (NADH)-tetrazolium oxidoreductase was demonstrated by the incubation of acetone-treated sections in a medium containing $0.5 \mathrm{mg} / \mathrm{ml} \mathrm{NBT}$, and $0.5 \mathrm{mg} / \mathrm{ml} \mathrm{NADH}$ dissolved in 0.05 M-phosphate buffer $(\mathrm{pH} 7 \cdot 5)$ for $30 \mathrm{~min}$ at $37^{\circ} \mathrm{C}$.

\section{BIOCHEMICAL TECHNIQUE}

\section{General operations}

Part of the excised chin gland was used for histochemical tests and the remainder was minced and used for experiments in vitro. The incubations were carried out for $4 \mathrm{hr}$ in $10 \mathrm{ml} \mathrm{Krebs-Henseleit} \mathrm{bicarbonate} \mathrm{buffer}(\mathrm{pH} \mathrm{7.4)}$ at $37^{\circ} \mathrm{C}$ in an atmosphere of $95 \% \mathrm{O}_{2}: 5 \% \mathrm{CO}_{2}$. The substrates used were $\left[7 \alpha-{ }^{3} \mathrm{H}\right]$ pregnenolone $(660 \cdot 0 \mathrm{mCi} / \mathrm{mmol}),\left[4-{ }^{14} \mathrm{C}\right]$ progesterone $(58.5 \mathrm{mCi} /$ $\mathrm{mmol})$ and $\left[4-{ }^{14} \mathrm{C}\right]$ testosterone $(58.2 \mathrm{mCi} / \mathrm{mmol})$, respectively. Details of the incubations are given in Table 1 . The incubations were carried out shortly after the animals were killed. Before extraction, $10 \mu \mathrm{g}$ each of pregnenolone and progesterone were added to the incubation mixture of Incubation 1; $10 \mu \mathrm{g}$ each of progesterone, androstenedione and testosterone to Incubation 2; and $10 \mu \mathrm{g}$ 
PLATE 1

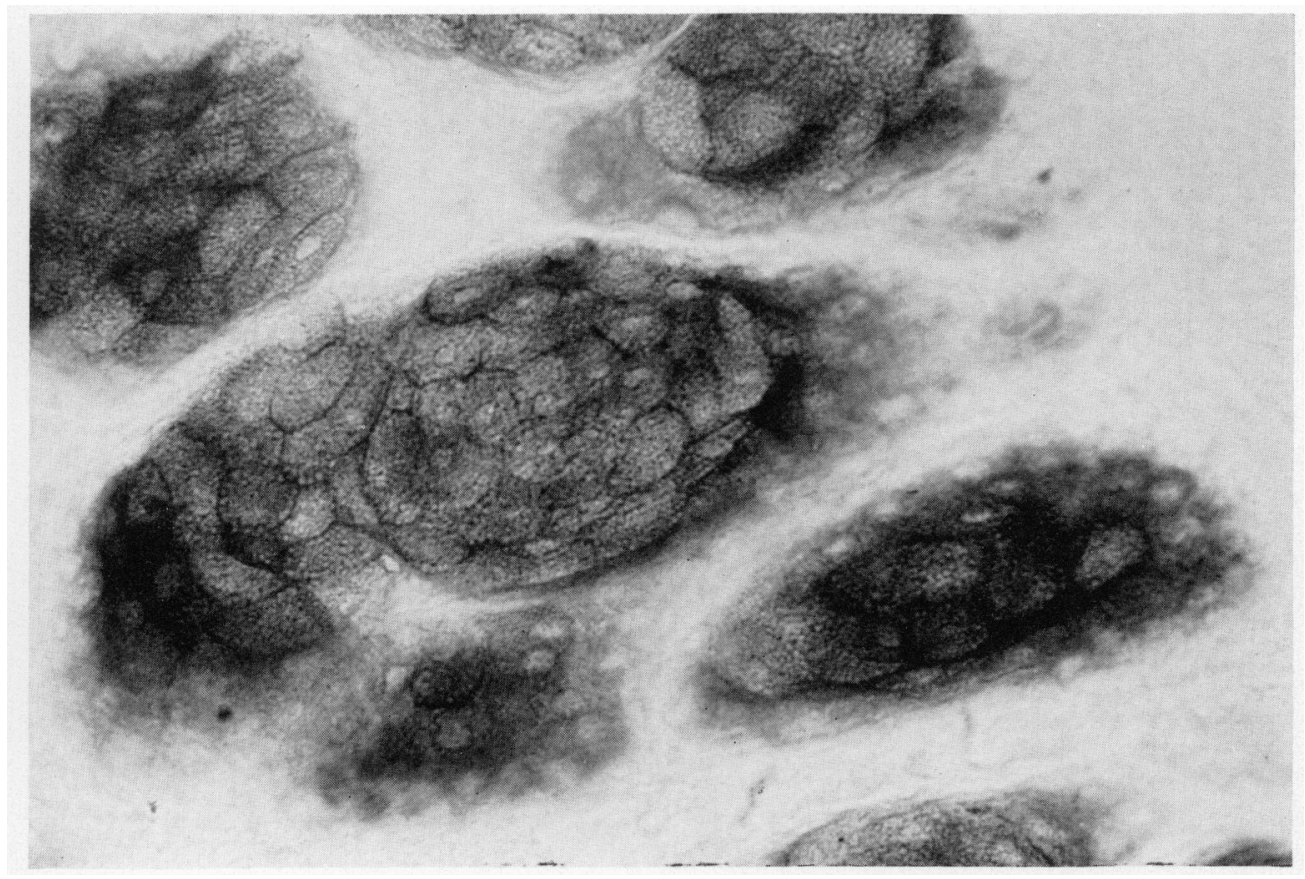

The scbaccous cells of the chin gland of a male cuis showing the presence of $17 \beta$-hydroxysteroid dehydrogenase. Note the weaker reaction of the peripheral undifferentiated cells. $\times 382$.

(Facing p. 54) 
each of androstenedione, $5 \alpha$-androstane-3,17-dione and testosterone to Incubation 3 as carriers for the calculation of recovery (Table 1 ).

Extraction and chromatography of steroids

The tissue was homogenized with the incubation medium, the steroids were extracted by repeated partition with diethyl ether, and the pooled organic phase was washed with three $2-\mathrm{ml}$ aliquots of water. The crude extract was first purified in the paper chromatographic system, light petroleum (b.p. $60^{\circ}$ to $\left.80^{\circ} \mathrm{C}\right)$ : methanol: water $(100: 75: 25$, by volume $)$. Further thin-layer chromatographic separations of steroids and their derivatives were similar to those given in detail elsewhere (Tam, 1972). The recovery of steroids was determined by gas-liquid chromatography of the carriers. The conditions of gas-liquid chromatography were identical to those previously described (Tam, 1971, 1972).

\section{Identification of steroids}

After the initial paper chromatography, known amounts of authentic $\left[7 \alpha-{ }^{3} \mathrm{H}\right]$ testosterone, $\left[7 \alpha-{ }^{3} \mathrm{H}\right]$ androstenedione and $\left[4-{ }^{14} \mathrm{C}\right]$ progesterone were added to the respective ${ }^{14} \mathrm{C}$-labelled and tritiated compounds formed by the tissue during the incubation. The characterization of steroids was by derivative formation, comparison of $R_{\mathrm{F}}$ values with reference compounds and, in the case of testosterone, androstenedione and progesterone, by the achievement of a constant ratio of ${ }^{3} \mathrm{H} \mathrm{ct} / \mathrm{min}:{ }^{14} \mathrm{C} \mathrm{ct} / \mathrm{min}$ after derivative formation. The unused precursors $\left[7 \alpha^{-3} \mathrm{H}\right]$ pregnenolone and $\left[4-{ }^{14} \mathrm{C}\right]$ progesterone were identified only by their $R_{\mathrm{F}}$ values as the parent compounds and acetates in paper chromatography and thin-layer chromatography.

No tritiated $5 \alpha$-androstane-3,17-dione was available, so this compound was identified by the comparison of $R_{\mathrm{F}}$ values in thin-layer chromatography as its sodium borohydride reduction product and the diacetate of the reduction product, with the corresponding derivatives, $5 \alpha$-androstane- $3 \beta, 17 \beta$-diol and $5 \alpha$-androstane, $3 \beta, 17 \beta$-diol diacetate, prepared from authentic $5 \alpha$-androstane3,17 -dione. The methods for the formation of steroid derivatives and the purification of chemicals were given previously (Tam, 1971).

\section{Detection and counting of radioactivity}

Radioactivity was detected on paper chromatography and thin-layer chromatography with a Panax radiochromatogram scanner. Counting of ${ }^{14} \mathrm{C}$ and tritium was carried out in a three-channel, automatic liquid scintillation spectrometer (Packard, Tri-Carb). The counting technique has been described elsewhere (Tam, Phillips \& Lofts, 1969).

\section{RESULTS}

HISTOLOGICAL AND HISTOCHEMICAI.

A positive reaction for $17 \beta$-hydroxysteroid dehydrogenase in the central areas of sebaceous acini was observed after incubation with testosterone (Plate 1). Little formazan was present in the undifferentiated sebaccous cells or in the 


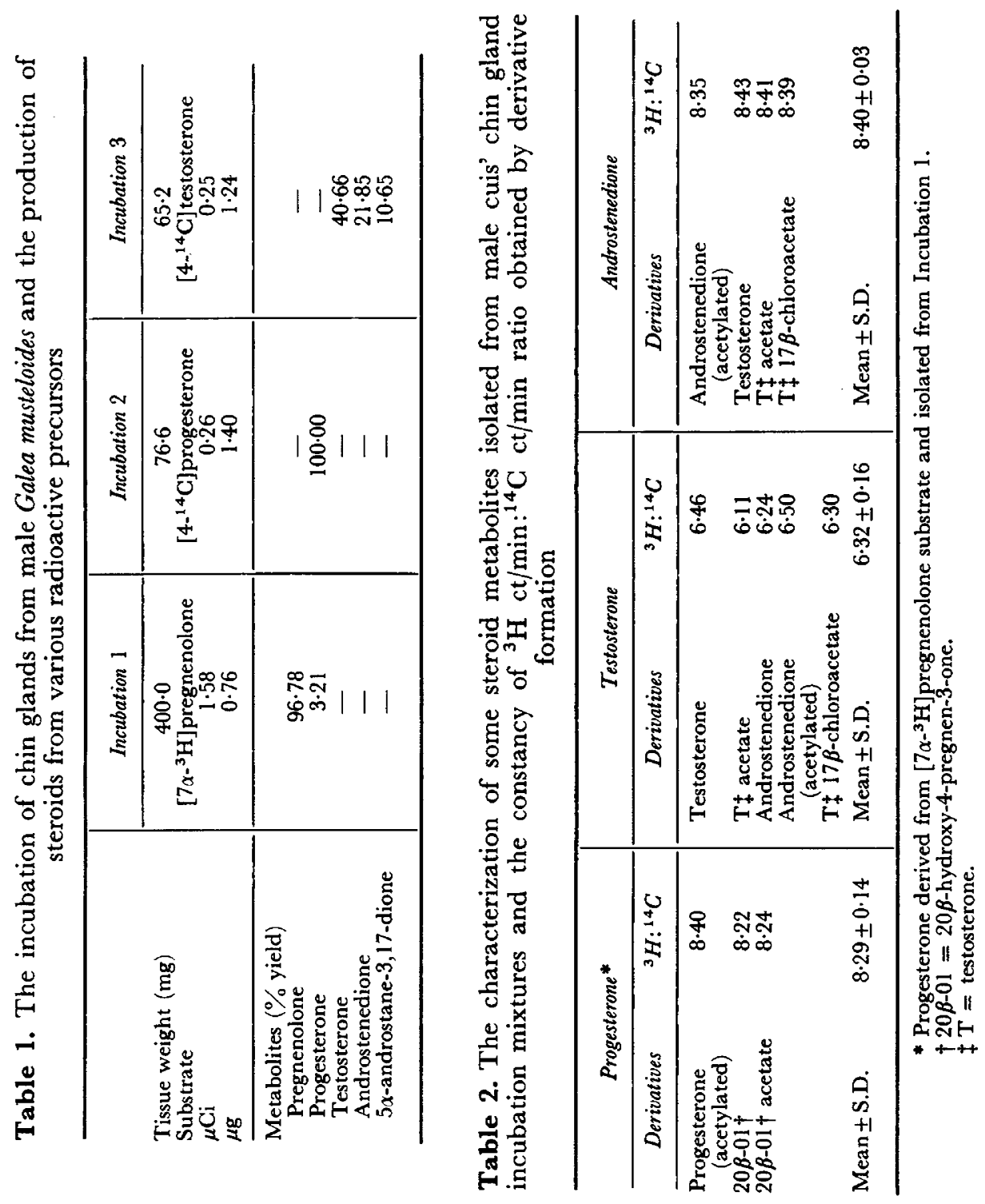


sebaceous secretion. A negative reaction was obtained with both DHEA and pregnenolone, indicating low activity or absence of 5 -ene-3 $\beta$-hydroxysteroid dehydrogenase activity.

These results were confirmed by examination of the control sections, where no positive reaction could be seen in the sebaceous cells, although the few hair follicles present caused reduction of NBT even in the absence of substrate or coenzyme. It was found essential to employ the preincubation rinse in acetone to prevent the spontaneous reduction of NBT by the sebaceous ducts.

The sebaceous acini were found to contain NADH-tetrazolium oxidoreductase, the reaction being strongest in the peripheral undifferentiated cells, and becoming progressively weaker with increasing cellular maturity. The enzyme was also present in the walls of the sebaceous ducts.

\section{BIOCHEMICAL}

The results of the experiments in vitro are given in Table 1. With the exception of Incubation 3, the compounds listed represent all the metabolites found in the incubations. The conversion of the pregnenolone substrate to progesterone was very low. Progesterone was not metabolized by the tissue. When $\left[4-{ }^{14} \mathrm{C}\right]-$ testosterone was used as a substrate, four radioactive peaks were observed in the initial paper radiochromatogram. Three of these were identified as $5 \alpha$-androstane-3,17-dione, androstenedione and unused testosterone. The fourth peak was in the origin of the chromatogram and was not further identified. The metabolism of testosterone by the chin gland was very active as the yields of androstenedione and $5 \alpha$-androstane-3,17-dione were high. The identification of metabolites by derivative formation where suitable labelled authentic compounds were available, is given in Table 2. The constancy of the ratio ${ }^{3} \mathrm{H}$ $\mathrm{ct} / \mathrm{min}:{ }^{14} \mathrm{C} \mathrm{ct} / \mathrm{min}$ of these compounds and their derivatives was achieved when the standard deviation was smaller than $5 \%$ of the mean. The $5 \alpha$-androstane-3,17-dione was identified by the similarity in $R_{\mathrm{F}}$ values of the isolated metabolite, its sodium borohydride reduction product and the diacetate of the reduction product, with authentic $5 \alpha$-androstane-3,17-dione $\left(R_{\mathrm{F}} 0 \cdot 68\right), 5 \alpha$-androstane$3 \beta, 17 \beta$-diol $\left(R_{\mathrm{F}} 0.36\right)$ and the diacetate of the diol $\left(R_{\mathrm{F}} 0.78\right)$ in the thin-layer chromatography system, benzene: ethyl acetate $(1: 1 \mathrm{v} / \mathrm{v})$.

\section{DISCUSSION}

The steroid metabolites identified here (Table 1) were also formed by human skin from similar precursors (Wotiz et al., 1956; Rongone, 1966; Faredin, Fazekas, Kókai, Tóth \& Julesz, 1967; Gallegos \& Berliner, 1967; Gomez \& Hsia, 1968). With the use of two different techniques, our results show that in the chin gland of the male G. musteloides, the following steroid enzymes are present: 5 -ene- $3 \beta$-hydroxysteroid dehydrogenase, 4-ene-5 $\alpha$-reductase and $17 \beta$-hydroxysteroid dehydrogenase.

Little information is available concerning the occurrence of steroid metabolizing enzymes in the sebaceous glands of vertebrates other than man. Baillie et al. (1966) reported the absence of hydroxysteroid dehydrogenase in the mouse and rat, and the presence of $17 \beta$-hydroxysteroid dehydrogenase in the preen glands of birds. Steroid utilization has also been demonstrated in cu- 
taneous glands of the frog, which secrete substances unpleasant to predators (Ferguson \& McGadey, 1970).

Human sebaceous glands have also been shown to contain $17 \beta$-hydroxysteroid dehydrogenase (Baillie et al., 1965). The sebaceous gland has never been shown to be able to metabolize progesterone. Thus, the chin gland in the male $G$. musteloides and the human sebaceous gland are equipped with a similar complement of steroid enzymes. The metabolites formed by the chin gland and by the human sebaceous gland are catabolic products of androgens. The stimulating effect on hair growth (Hooker \& Pfeiffer, 1943), mitosis and sebum production in sebaceous glands (Ebling, Ebling, McCaffery \& Skinner, 1971) by androgens is well established. It is, therefore, most likely that the mammalian sebaceous glands are not only essential for the maintenance of hair growth, but also function as an accessory sexual organ. Androgens are required to elicit these functions. In G. musteloides, the male is required to induce oestrus (Weir, 1971). This involves a sexual display (chin-rump follow) in which the male applies the chin gland to the rump of the female (Rood \& Weir, 1970). The mechanism whereby this display works is not known, but it is likely to be one of tactile and chemical stimulation, with sebum from the chin gland and other parts of the skin of the male perhaps playing an active rôle.

The advantages of a system where the activity of skin glands is controlled by androgens can be appreciated when their rôle in mammalian communication is considered. It has been shown by examination of anal, inguinal and submandibular glands of the Australian wild rabbit that a statistically significant correlation exists between the social status of the animals and the weight of their glands. Histological examination also showed similar correlations of the secretory activities of the glands with social ranking and sexual activity of the animals (Mykytowycz, 1970).

The demonstration that skin gland activity is dependent upon the social and reproductive status of an animal correlates well with the observations that sebaceous glands regress after castration and are responsive to androgen replacement therapy. Similar effects of castration have been found in the chin gland of the male cuis (Weir, 1973).

The function of steroid metabolizing enzymes in sebaceous glands is poorly understood, but it has been pointed out that the hormonal microenvironment of a tissue is likely to be affected by the presence of an active catabolic pathway (Gomez \& Hsia, 1968). It may be possible to determine some of the functions of these enzymes by studying the effect of a competitive metabolic inhibitor, such as an analogue of testosterone, upon the activity of sebaceous glands.

\section{ACKNOWLEDGMENTS}

The authors express their gratitude to Dr B. J. Weir who supplied the biological materials, to Dr P. A. Collins who supplied the $5 \alpha$-androstane-3,17-dione used as the standard in these experiments and to Dr I. W. Rowlands for reading the manuscript. The technical assistance of Mrs J. M. Gray is also gratefully acknowledged. This work was financially supported by the Ford Foundation and the Medical Research Council. 


\section{REFERENCES}

Baillie, A. H., Calman, K. G. \& Milne, J. A. (1965) Histochemical distribution of hydroxysteroid dehydrogenases in human skin. Br. J. Derm. 77, 610 .

Baillie, A. H., Ferguson, M. M. \& Hart, D. MaK. (1966) Developments in steroid histochemistry. Academic Press, London.

Dryden, G. L. \& Conaway, G. H. (1967) The origin and hormonal control of scent production in Suncus murinus. 7. Mammal. 48, 420.

Ebling, F. J., Ebling, E., McGaffery, V. \& Skinner, J. (1971) The response of the sebaceous glands of the hypophysectomised-castrated male rat to $5 \alpha$-dihydrotestosterone, androstenedione, dehydroepiandrosterone and androsterone. 7. Endocr. 51, 181.

Faredin, I., Fazekas, A. G., Kókal, K., Tóth, I. \& Julesz, M. (1967) The in vitro metabolism of $4-{ }^{14} \mathrm{C}$ dehydroepiandrosterone by human male pubic skin. Eur. F. Steroids, 2, 223.

Ferguson, M. M. \& McGadey, J. (1970) Steroid utilisation by amphibian skin. Histochemie, 22, 36.

Gallegos, A. J. \& Berliner, D. L. (1967) Transformation and conjugation of dehydroepiandrosterone by human skin. 7. clin. Endocr. Metab. 27, 1214.

GL.ENN, E. M. \& GRAY, J. (1965) Effect of various hormones on the growth and histology of the gerbil (Meriones unguiculatus) abdominal sebaceous gland pad. Endocrinology, 76, 1115.

Gomez, E. C. \& Hsia, S. L. (1968) In vitro metabolism of testosterone- $4-{ }^{14} \mathrm{C}$ and $\Delta^{4}$-androstene-3,17dione-4- ${ }^{14} \mathrm{C}$ in human skin. Biochemistry, N.Y. 7, 24.

Hooker, C. H. \& Preiffer, C. A. (1943) Effects of sex hormones on body growth, skin, hair and sebaceous glands in the rat. Endocrinology, 32, 69.

MaRTan, J. (1962) Effect of castration and androgen replacement on the supracaudal gland of the male guinea-pig. J. Morph. 110, 285.

Martan, J. \& PRICE, D. (1967) Comparative responsiveness of supracaudal and other sebaceous glands in male and female guinea-pigs to hormones. $\mathcal{F}$. Morph. 121, 209.

Mitchell, O. G. (1967) The supposed role of the gerbil ventral gland in reproduction. 7. Mammal. 48, 142.

Montagna, W. (1963) Comparative aspects of sebaceous glands. In: Advances in the Biology of Skin, Vol. 4. Eds. W. Montagna, R. A. Ellis and A. F. Silver. Pergamon Press, London.

MYкутоWусz, R. (1970) The role of skin glands in mammalian communication. In: Advances in Chemoreception, Vol. 1, p. 327. Eds. J. W. Johnston, Jr, D. G. Moulton and A. Turk. Appleton-CenturyCrofts, New York.

Rongone, E. L. (1966) Testosterone metabolism by human male mammary skin. Steroids, 7, 489.

Rood, J. P. \& WeIR, B. J. (1970) Reproduction in female wild guinea-pigs. F. Reprod. Fert. 23, 393.

Strauss, J. S. \& Ebling, F. J. (1970) Control and function of skin glands in mammals. In: Hormones and the Environment, p. 341 . Eds. G. K. Benson and J. G. Phillips. Mem. Soc. Endocr. No. 18. Cambridge University Press, London.

TAM, W. H. (1971) The production of hormonal steroids by ovarian tissue of the chinchilla (Chinchilla laniger). $\mathcal{J}$. Endocr. 50, 267.

TAM, W. H. (1972) Steroid metabolic pathways in the ovary of the chinchilla (Chinchilla laniger). $\mathcal{J}$. Endocr, 52, 37.

TAm, W. H., Phillips, J. G. \& Lofts, B. (1969) Seasonal changes in the in vitro production of testicular androgens by the cobra (Naja naja Linn.). Gen. $\mathcal{E}^{\circ}$ compar. Endocr. 13, 117.

Thiessen, D. D., Friend, H. C. \& Lindzey, G. (1968) Androgen control of territorial marking in the mongolian gerbil. Science, N.Y. 160, 432.

WEIR, B. J. (1970) The management and breeding of some more hystricomorph rodents. Lab. Anim. 4, 83.

WEIR, B. J. (1971) The evocation of oestrus in the cuis, Galea musteloides. F. Reprod. Fert. 26, 405.

WEIR, B. J. (1973) The rôle of the male in the evocation of oestrus in the cuis, Galea musteloides (Rodentia: Hystricomorpha). 7. Reprod. Fert. Suppl. (in press).

Wotiz, H. H., Mescon, H., Doppel, H. \& Lemon, H. M. (1956) The in vitro metabolism of testosterone by human skin. $\mathcal{J}$. invest. Derm. 26, 113. 